\title{
Pengembangan Wisata Religi Petilasan Pangeran Benowo Di Kecamatan Bener Kabupaten Purworejo
}

\author{
${ }^{1}$ Junaidi Safitri *, ${ }^{2}$ Dyah Hendrawati \\ ${ }^{1)}$ Program Studi Ilmu Ekonomi Islam, FIAI Universitas Islam Indonesia Yogyakarta \\ ${ }^{2)}$ Program Studi Arsitektur, FTSP Universitas Islam Indonesia Yogyakarta \\ *Corresponding Email: junaidi.safitri@uii.ac.id
}

\begin{abstract}
ABSTRAK
Keberadaan situs religi saat ini sudah sangat popular di tengah-tengah masyarakat, sehingga keberadaan situs religi ini tidak hanya sekedar situs untuk dikunjungi sebagai tujuan untuk bertakziyah namun juga seiring dengan perkembangan zaman situs religi yang ada tersebut dapat memberikan nilai keekonomisan yang lain yaitu sebagai media untuk berdakwah dan berniaga.

Salah satu situs religi tersebut berada di Desa Benowo, Kecamatan Bener, Kabupaten Purworejo. yaitu situs petilasan Pangeran Benowo yang menjadi cikal bakal keberadaan desa Benowo di Kabupaten Purworejo. Pangeran Benowo merupakan anak dari raja kerajaan Pajang yang bernama sultan Hadiwijaya atau lebih dikenal Jaka Tingkir, dimana pada masa penjajahan Belanda kira-kira tahun 1600M Pangeran Benowo bersama para pengikutnya menepi atau tirakat di suatu tempat dalam perjalanan dari kerajaan Pajang menuju kerajaan Mataram dan singgah di Pegunungan Menoreh, tepatnya di sebuah bukit yang di namakan Batur, yang saat ini tempat tersebut di kenal masyarakat umum dengan Desa Benowo.

Petilasan Pangeran Benowo tersebut saat ini di jadikan sebagai wisata religi yang dapat menjadi daya tarik tersendiri wisatawan untuk berkunjung ke desa Benowo. Wisatawan dapat melihat nilai histori dari keberadaan petilasan Pangeran Benowo tersebut diantaranya adalah adanya sendang yang digunakan oleh para pengikut pangeran Benowo untuk minum dan membersihkan diri, serta terdapat barang-barang yang dipergunakan oleh rombongan Pangeran Benowo antara lain piring keramik, ulegan batu, payung, dan lainlain.

Adanya wisata minat khusus religi ini menjadikan pengelola desa wisata Benowo mulai berbenah dengan mengoptimalkan potensi wisata yang ada baik wisata alam, budaya dan kesenian untuk dapat menarik lebih banyak wisatawan untuk berkunjung ke desa wisata Benowo. Kelemahan pengembangan desa wisata religi di Desa Benwo ini adalah 1) Tidak adanya perencanaan pengembangan potensi wisata religi yang ada, dan 2) Wisata Religi Pangeran Benowo belum dikelola dengan baik

Berdasarkan permasalahan tersebut diatas pengabdi dan mitra akan menyelesaikan permasalahan tersebut di atas melalui kegiatan pelatihan perencanaan pengembangan wisata religi petilasan Pangeran Benowo, dan 2) Pendampingan pengelolaan wisata religi melalui penguatan sumber daya manusia. Sehingga target luaran dari kegiatan pengabdian ini adalah 1). Terciptanya pengembangan wisata religi di desa Benowo, 2) Terciptanya tata kelola wisata religi
\end{abstract}

Kata Kunci: Benowo, pengembangan, wisata religi

\section{ABSTRACT}

The existence of religious sites is currently very popular among the community, so that the existence of this religious site is not only a site to be visited as a destination for takziyah but also along with the development of the existing religious sites can provide other economic values, namely as a medium for preaching and trading.

One such religious site is located in Benowo Village, Bener District, Purworejo Regency. namely the Prince Benowo site which became the forerunner to the existence of Benowo Village in Purworejo Regency. Prince Benowo is the son of the king of the Pajang kingdom named sultan Hadiwijaya or better known as Jaka Tingkir, where during the Dutch colonial period around 1600 AD Prince Benowo and his followers stepped aside or took refuge somewhere on the way from the Pajang kingdom to the Mataram kingdom and stopped at Menoreh Mountains, to be precise on a hill called Batur, which is currently known to the general 
public as Benowo Village.

Prince Benowo's petilasan is currently being used as religious tourism which can be a special attraction for tourists to visit Benowo village. Tourists can see the historical value of the existence of Prince Benowo's petilasan, including the existence of the sendang used by the followers of Prince Benowo for drinking and cleaning, as well as items used by Prince Benowo's entourage, including ceramic plates, stone bowls, umbrellas, and etc.

The existence of special religious interest tourism has made the managers of the Benowo tourism village start to improve by optimizing the existing tourism potential, both natural, cultural and artistic tourism to be able to attract more tourists to visit Benowo tourism village. The weaknesses of the development of this religious tourism village in Benwo Village are 1) There is no development plan for the development of existing religious tourism potential, and 2) Prince Benowo Religious Tourism has not been managed properly

Based on the above problems, the service and partners will solve the above problems through planning training activities for the development of religious tourism, Prince Benowo, and 2) Assistance in the management of religious tourism through strengthening human resources. So that the output target of this service activity is 1). The creation of religious tourism development in Benowo village, 2) The creation of religious tourism governance

Keywords: Benowo, development, religious tourism

\section{PENDAHULUAN}

Wisata religius merupakan wisata yang menekankan pada destinasi wisata bersifat religius. Indonesia memiliki banyak sekali destinasi wisata religius, bahkan jumlahnya mengalahkan Malaysia yang saat ini menduduki peringkat pertama wisata halal versi GMTI. Beberapa destinasi wisata religius yang cukup banyak di Indonesia seperti makam para wali dan raja-raja kerajaan Islam, istana kerajaan Islam, masjid dan petilsan-petilsan tokoh-tokoh agama ataupun raja.

Salah satu wisata religi tersebut berada di Desa Benowo, Kecamatan Bener Kabuapaten Purworejo Jawa Tengah. Wisata religi yang ada di Desa Benowo berupa petilasan Pangeran Benowo, yang merupakan anak dari raja kerajaan Pajang yang bernama sultan Hadiwijaya atau lebih dikenal Jaka Tingkir, dimana pada masa penjajahan Belanda kira-kira tahun 1600M Pangeran Benowo bersama para pengikutnya menepi atau tirakat di suatu tempat dalam perjalanan dari kerajaan Pajang menuju kerajaan Mataram dan singgah di Pegunungan Menoreh, tepatnya di sebuah bukit yang di namakan Batur, yang saat ini tempat tersebut di kenal masyarakat umum dengan Desa Benowo.

Desa Benowo memiliki Luas wilayah 329,7 HA. Topografi wilayah Desa Benowo berupa kawasan perbukitan yang berada pada deretan perbukitan menoreh dengan letak pada ketinggian 950 mdpl. Sumber daya manusia di Desa Benowo kurang lebih sebanyak 1.141 orang atau sebanyak kurang lebih 287 KK yang terbagi di 8 dusun, yaitu Dusun pabungan, Dusun Sikebek, Dusun Keseneng Wetan, Dusun Benowo, Dusun Keseneng Lor, Dusun Keboan, Dusun Sirebut. Batas Desa Benowo yaitu :Sebelah utara: desa Kalirejo, Kec.Salaman, Kab.magelang, Jawa Tengah, Sebelah Selatan: Desa Ngargosari, Kec.Loano,Kab.Purworejo, Jawa Tengah, Sebelat Barat :Desa Cacaban Kidul dan Desa Kalitapas, Kec.Bener, Kab.Purworejo, Jawa Tengah, Sebelah Timur:Desa Pagerharjo, Kec.Samigaluh, Kab.Kulon Progo Daerah Istimewa Yogyakarta. 
Mayoritas penduduk di Desa Benowo adalah bermata pencaharian sebagai petani dan peternak. Pendidikan masyarakat rata-rata di dominasi berpendidikan Sekolah Menengah Pertama (SMP). Tanaman perkebunan yang ada di Desa Benowo berupa tanaman cengkeh, Kopi, Kayu dan tanaman sayur lainnya serta buah-buahan seperti rambutan, durian, ketela, duku, kokosan, pisang dan mlinjo.

Selain wisata religi Desa Benowo memiliki Potensi unggulan berupa wisata alam dan pegunungan yaitu Gunung Kunir, air terjun Curug Batur, Curug Benawan dan Curug Padusan serta adanya wisata religi yang berupa petilasan Pangeran Benowo dan sendang benowo. Adanya pengembangan jalur bedah Menoreh yang menghubungkan antara bandara baru Yogyakarta ke Borobudur membawa dampak pengembangan wisata Desa Benowo ke depannya, di karenakan jalur tersebut melalui Desa Benowo. Jumlah kunjungan wisatawan religi ke Desa Wisata Benowo selama ini didominasi oleh wisatawan local dari Kabuapaten Purworejo, Magelang, Solo dan Yogyakarta. Rendahnya jumlah kunjungan wisatawan religi tersebut akibat dari:

1. Wisata Religi yang ada saat ini belum terkelola dengan baik

2. Promosi/pemasaran desa wisata kurang optimal

2. Belum adanya pengembangan wisata religi dalam mendukung wisata alam yang ada

3. Tata kelola kelembagaan desa wisata yang tidak baik

Persoalan - persoalan tersebut di atas merupakan persoalan yang harus segera di selesaikan supaya Desa wisata Benowo dapat menjadi daerah tujuan wisata unggulan di Kabupaten Purworejo tanpa meninggalkan keunikan dan norma-norma tradisi yang kental serta kekayaan alam berdasarkan nilai-nilai kearifan lokal masyarakat dalam mendukung pengembangan potensi Desa wisata Benowo.

\section{METODE PENGABDIAN}

Berdasarkan Permasalahan-permasalahan yang ada, maka telah disepakati untuk menyelesaikan persolan tersebut melalui pelatihan, dan pendampingan. Model pemberdayaan masyarakat untuk mengatasi persolan di atas menggunakan metode partisipatif Participatory Rural Apraisal (PRA). Pertimbangan dipilihnya metode ini adalah bahwa yang menghadapi masalah adalah mitra, oleh karena itu keterlibatan mitra dalam penentuan pemecahan masalah yang dihadapi dan penyelesaiannya sangat diperlukan.

\section{HASIL DAN PEMBAHASAN}

\section{Focus Group Discusion}

Kegiatan awal dari kegiatan pengabdian ini, pengabdi dan mitra menyepakati di adakan kegiatan focus group discussion, tujuan dari kegiatan ini adalah untuk menggali persoalan-persoalan dan keinginan dari pemerintah desa, pengelola desa wisata, dan masyarakat dalam pengembangan wisata religi petilasan Pangeran Benowo.( Gambar 1) 
JAMALI - Volume. 02, Issue. 02, September 2020

\section{Pendampingan Pengelolaan Wisata Religi}

Kegiatan ini merupakan kegiatan dari tindak lanjut FGD yang telah di laksanakan. Dari hasil kegiatan sebelumnya mengharapkan bahwa pengelolaan desa wisata di jadikan satu kelembagaan Desa sehingga kedepan tidak menimbulkan konflik kepentingan. Hasil dari kegiatan ini yaitu menghasilkan lembaga baru, yaitu Badan Pengelola Desa Wisata Benowo (BPDB) memiliki beberapa tujuan, seperti :

a) Mencipatakan lingkungan yang indah dan bersih terhadap desa wisata Benowo

b) Meningkatkan pengetahuan masyarakat desa terhadap desa wisata Benowo

c) Menjadikan desa wisata Benowo menarik banyak pengunjung oleh kreativitas yang dilakukan

d) Membuat kinerja dan aktivitas lebih maksimal dengan kerjasama antar masyarakat desa dengan BPDB

BPDB memiliki Fungsi sebagai berikut :

a) Membantu memasarkan, melakukan branding dan positioning desa wisata Benowo

b) Mengelola produk yang dimiliki oleh desa wisata benowo

c) Melakukan proses perencanaan, implementasi dan evaluasi program kerja yang berkaitan dengan desa wisata Benowo

d) Memberi informasi kepada wisatawan serta membantu masyarakat dalam pemanfaatan desa wisata. Badan Pengelola Desa Wisata Benowo (BPDB) memiliki struktur organisasi (Gambar 3.2)

\subsection{Pendampingan Pengembangan wisata Religi Pangeran Benowo}

Dalam mendukung pengembangan wisata religi di Desa Benowo, dalam pelaksanaan pengabdian ini pengabdi diminta membuat masterplan keseluruhan potensi desa Benowo sehingga kedepan bisa di anggarkan dalam penganggaran dana desa.(Gambar 3.2)

\section{KESIMPULAN}

Kegiatan pengabdian pada masyarakat yang berupa pengembangan wisata religi petilasan Pangeran Benowo di Kecamatan Bener Kabuapaten Purworejo. Kegiatan pengabdian ini dapat terlaksana sesuai dengan tujuan dan rencana pengabdian, yang mendapat dukungan penuh seluruh pemerintah desa Benowo, pengelola wisata dan masyarakat sehingga hasil dari kegiatan pengabdian ini menghasilkan luaran berupa 1). Terciptanya pengembangan wisata religi di desa Benowo dalam bentuk masterplan dan 2) Terciptanya tata kelola wisata religi melalui pembentukan lembaga baru. 


\section{UCAPAN TERIMA KASIH}

Ucapan terima kasih terutama ditujukan kepada Direktorat Penelitian dan Pengabdian Masyarakat (DPPM) UII atas pendanaan penuh pada Hibah ini. Ucapan terima kasih juga disampaikan kepada masyarakat desa Benowo kecamatan Bener Kabupaten Purworejo Jawa Tengah

\section{DAFTAR PUSTAKA}

https://insanwisata.com/desa-wisata-benowo/ di akses 20 september 2020

https://giriaruna.com/desa-wisata-benowo-purworejo-rintisan-wisata-jawa-tengah/ di akses 20 september 2020 


\section{Gambar}

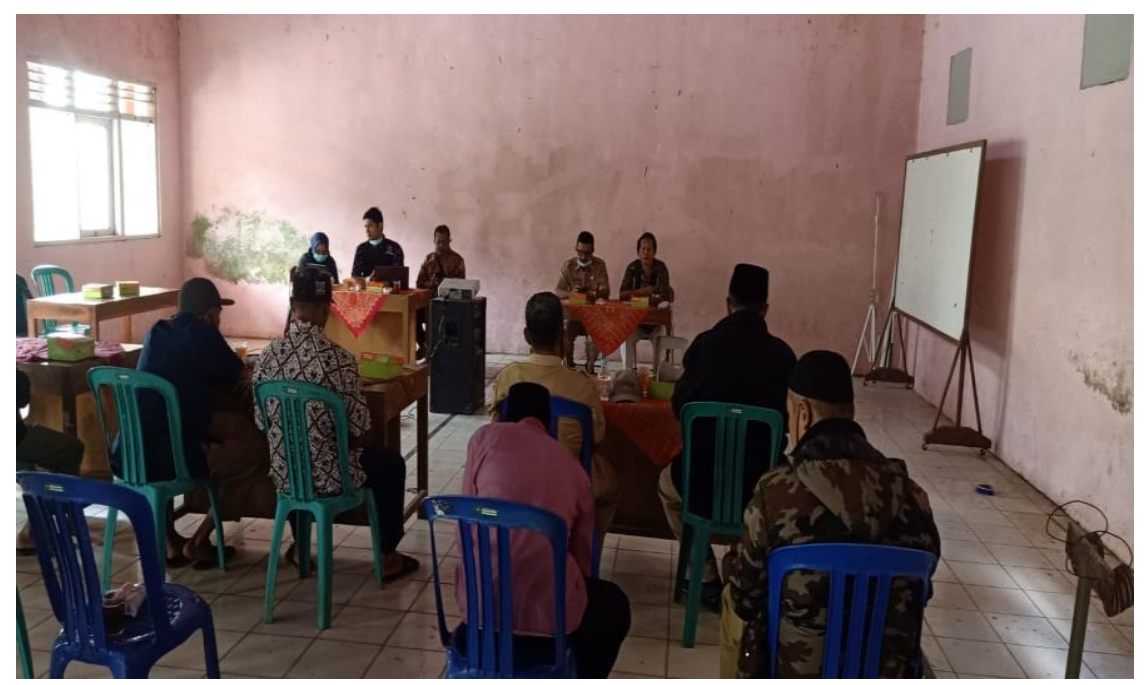

Gambar 3.1 Focus Group Discusion

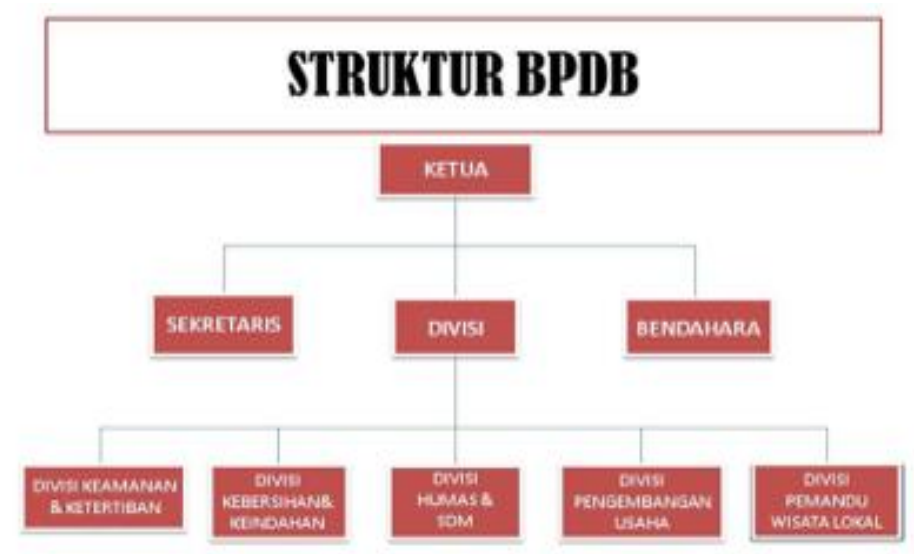

Gambar 3.2 Struktur Lembaga desa wisata yang baru

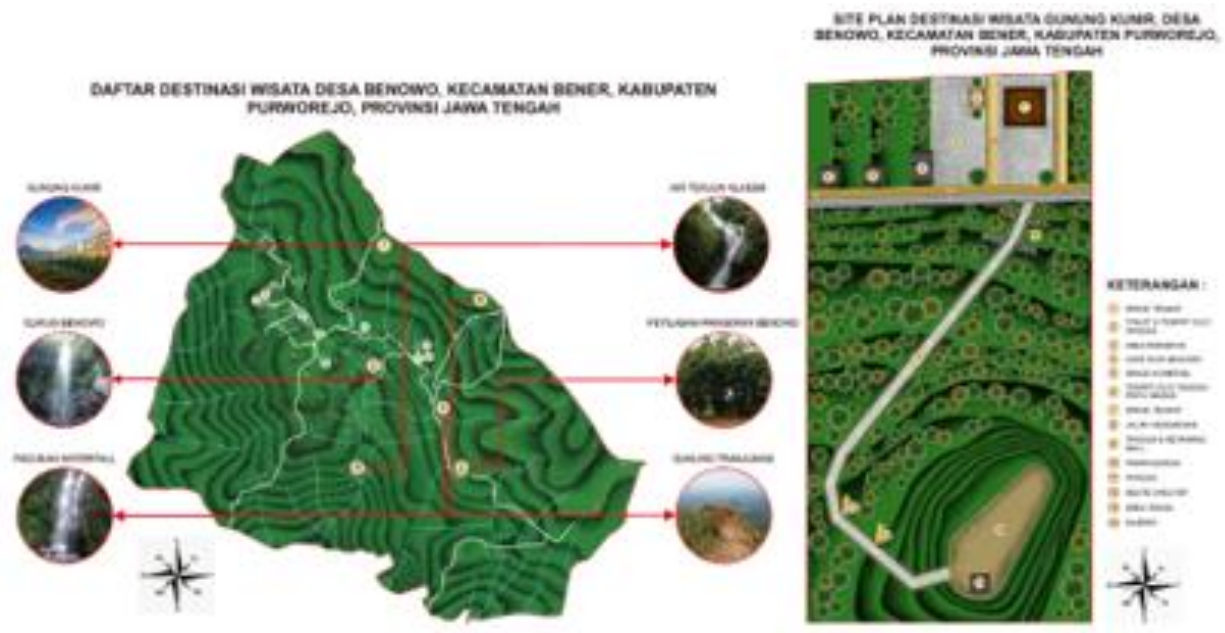

Gambar 3.2 Masterplan pengembangan wisata di Benowo 